\title{
Benefits of the Pilates Method in Preventing Elderly Falls
}

\author{
Marcelo De Maio Nascimento* \\ Department of Physical Education, Federal University of the São Francisco Valley, Brazil
}

Submission: May 16, 2018; Published: May 22, 2018

*Corresponding author: Marcelo De Maio Nascimento, Department of Physical Education, Federal University of the São Francisco Valley, Brazil, Tel: +55/87-21016857; Email: marcelo.nascimento@univasf.edu.br

\begin{abstract}
The proportion of the elderly population has increased considerably in the world; this requires the transformation of public health policies for the coming decades. One of the major health problems of the elderly population is falls, responsible for injuries, days of hospitalization and low functional independence capacity. Different studies have revealed the effects of Pilates practice on the prevention of falls in the elderly. The method is well accepted by the elderly population and able to increase levels of muscle strength, flexibility, balance, functional mobility, body awareness, confidence in balance, reducing fear of falls.
\end{abstract}

Keywords: Pilates; Aging; Falls

\section{Short Communication}

The proportion of the elderly population has increased considerably in recent decades. It is estimated that in the year 2050, the world population presents 2 million people over 65: a population more susceptible to chronic and degenerative diseases. In the case of Brazil, for example, it is estimated that in 2050 it will have the fifth largest population in the world, 253 million inhabitants, and 9 million will be over eighty years old. Therefore, issues of human aging are a challenge for public policies on health and social development $[1,2]$. Human aging is considered as a process and not pathology [3]. This process determines a series of physical changes, which is followed by the progressive reduction of the functional capacities, necessary for the resolution of activities of daily living [4]. Although aging occurs differently for each person, it cannot be avoided. However, by adopting an active lifestyle, it is possible to prolong the years of life in a healthy way [5]. In this perspective, the regular practice of physical exercises presents itself as a measure of low cost, capable of increasing the physical condition of the elderly and, consequently, the functional capacity. In this perspective, the regular practice of physical exercises presents itself as a measure of low cost, capable of increasing the physical condition of the elderly and, consequently, their functional capacity. Through physical exercises, the elderly can expand their social network of friendships, avoiding isolation, depression, insomnia, increasing the perception of quality of life and well-being [6-8].
Among the sporting modalities advised for the elderly population and well accepted, is Pilates [9]. The method is composed of a series of exercises developed by Joseph Pilates in the 1930s. Pilates also called his method as "contrology", because exercises seek control and awareness of body movement [10]. The exercises can either be practiced on equipment, regulated by a spring system, or on the ground, using only body weight. The conceptual basis of training consists of body-mind integration, achieved from functional challenges. Pilates corrects postural deficits by developing stability of the "powerhouse" muscles, a region that involves more internal muscles, located from the peripelvic region to the diaphragm. This set of muscles is especially responsible for postural control and stability of the body.

\section{The Magnitude of Falls, Among the Elderly Population}

According to the World Health Organization [11], approximately $28-35 \%$ of people 65 and older fall yearly, the rate increases to $32-42 \%$ among older people over age 70 , being the most common case among women. The consequences of a fall can be serious, it is estimated that $10 \%$ of them generate soft tissue injuries, fractures and brain trauma, which is followed by days of hospitalization. In Brazil, for example, according to data released by the Ministry of Health on hospital admissions for the elderly by falls, between the years 2005 and 2010, 399,681 cases were identified [12]. The services for authorization of 
hospitalization in this period was USD 132.821.221,69. These data demonstrate the need to develop actions to prevent falls in the elderly in Brazil.

\section{Benefits of the Pilates Method to Preventing Elderly Falls}

Systematic review studies [11,13], meta-analysis [14] and experimental $[15,16]$ have shown the potential of Pilates exercises to prevent falls in the elderly. This is due to the following factors:

a) Increased levels of muscle strength in the lower limbs, dorsal and abdominal muscles [17];

b) Better levels of flexibility and stretching [18];

c) Stimulation of the static and dynamic balance regulation system: visual, vestibular and proprioceptive apparatus $[19,20]$;

d) Improves gait pattern: increased speed of strides, length and cadence [21];

e) Reduced fear of falls and increased confidence in balance [22].

In addition, in order for the risk of falls to be reduced to the maximum, physical exercise should be associated with fall prevention strategies $[23,24]$, such as:

a) Multifactorial assessment of intrinsic and extrinsic aspects related to falls;

b) Single clinical evaluation: protocols and questionnaires;

c) Educational interventions; and

d) Actions to prevent falls at home.

\section{References}

1. WHO-World Health Organization (2014) Ageing well must be global priority, warns UN health agency in new study.

2. WHO-World Health Organization (2017) Healthy ageing: moving forward. Bull World Heal Organ 95(11): 730-730.

3. JR Beard, AM Officer, AK Cassels (2016) The world report on ageing and health. Gerontologist 56(2):163-166.

4. WHO-World Health Organization (2015) Ageing and health

5. WHO-World Hearth Organization (2014) What is active ageing?

6. J Viña, L Rodriguez Mañas, A Salvador Pascual, FJ Tarazona Santabalbina, MC Gomez Cabrera (2016) Exercise: the lifelong supplement for healthy ageing and slowing down the onset of frailty. J Physiol 594(8): 1989-1999.

7. JS Mc Phee, DP French, D Jackson, J Nazroo, N Pendleton, et al. (2016) Physical activity in older age: Perspectives for healthy ageing and frailty. Biogerontology 17(3): 567-580.
8. E Giannouli, O Bock, S Mellone, W Zijlstra (2016) Mobility in Old Age: Capacity Is Not Performance. Biomed Res Int 2016: 1-8.

9. T Iulian Doru, G Vasilica, T Maria, B Claudia Camelia (2013) Pilates Principles - Psychological Resources for Efficiency Increase of Fitness Programs for Adults. Procedia - Soc Behav Sci 84: 658-662.

10. P Latey (2001) The Pilates method: History and philosophy. J Bodyw Mov Ther 5(4): 275-282.

11.WHO-World Health Organization (2007) Global Report on Falls Prevention in Older Age. Community Health (Bristol) 53.

12. IFO Barros, MB Pereira, TH Weiller, ETR Anversa (2015) Internações hospitalares por quedas em idosos brasileiros e os custos correspondentes no âmbito do Sistema Único de Saúde. Rev Kairós Gerontol 18(4): 63-80.

13. PB Engers, AJ Rombaldi, EG Portella, MC da Silva (2016) Efeitos da prática do método Pilates em idosos: Uma revisão sistemática. Rev Bras Reumatol 56(4): 352-365.

14.GC Miyamoto, LOP Costa, CMN Cabral (2013) Efficacy of the Pilates method for pain and disability in patients with chronic nonspecific low back pain: A systematic review with meta-analysis. Braz J Phys Ther 17(6): 517-532.

15. L Donath, R Roth, C Hurlimann, L Zahner, O Faude (2016) Pilates vs. Balance Training in Healthy Community- Dwelling Seniors: A 3-arm, Randomized Controlled. Int J Sports Med 37(3): 202-210.

16.J Bertoli, GM Biduski, C De la Rocha Freitas (2017) Six weeks of Mat Pilates training are enough to improve functional capacity in elderly women. J Bodyw Mov Ther 21(4): 1003-1008.

17. LC De Oliveira, RG De Oliveira, DAA Pires Oliveira (2015) Effects of Pilates on muscle strength, postural balance and quality of life of older adults: A randomized, controlled, clinical trial. J Phys Ther Sci 27(3): 871-876.

18. S De Azevedo, J Simas, Z Machado, V Jonck (2014) The effect of Pilates method on elderly flexibility. Fisioter em Mov 27(2): 181-188.

19. IPC Coriolano, VR Pérez, MM Nascimento, HJ Appell (2012) The Pilates Method to Improve Body Balance in the Elderly. Arch Exerc Heal Dis 3(3): 188-193.

20. MS Tomruk, MZ Uz, B Kara, E Idiman (2016) Effects of Pilates exercises on sensory interaction, postural control and fatigue in patients with multiple sclerosis. Mult Scler Relat Disord 7: 70-73.

21. RW Pata, K Lord, J Lamb (2014) The effect of Pilates based exercise on mobility, postural stabilit, and balance in order to decrease fall risk in older adults. J Bodyw Mov Ther 18(3): 361-367.

22. D Cruz Díaz, A Martínez Amat, MJ Torre Cruz, RA Casuso, N Mendoza, et al. (2015) Effects of a six-week Pilates intervention on balance and fear of falling in women aged over 65 with chronic low-back pain: A randomized controlled trial. Maturitas 82(4): 371-376.

23. YL Michael, JS Lin, EP Whitlock, R Gold, R Fu, et al. (2010) Interventions to Prevent Falls in Older Adults: An Updated Systematic Review 1(80) 391-392.

24.S Thomas, S Mackintosh, J Halbert (2010) Does the "Otago exercise programme" reduce mortality and falls in older adults?: A systematic review and meta-analysis. Age Ageing 39(6): 681-687. 
This work is licensed under Creative Commons Attribution 4.0 License

DOI:10.19080/JPFMTS.2018.04.555630

\section{Your next submission with Juniper Publishers} will reach you the below assets

- Quality Editorial service

- Swift Peer Review

- Reprints availability

- E-prints Service

- Manuscript Podcast for convenient understanding

- Global attainment for your research

- Manuscript accessibility in different formats ( Pdf, E-pub, Full Text, Audio)

- Unceasing customer service

Track the below URL for one-step submission https://juniperpublishers.com/online-submission.php 